
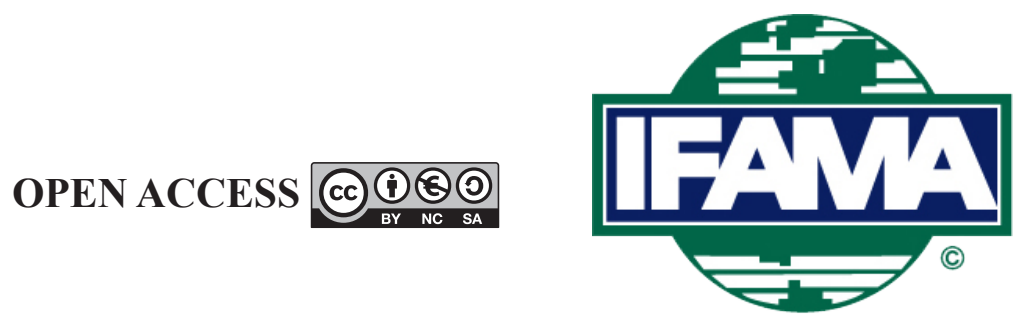

International Food and Agribusiness Management Review

Volume 23 Issue 2, 2020; DOI: 10.22434/IFAMR2019.0118

Received: 2 April 2019 / Accepted: 23 October 2019

\title{
Farm expansion under credit constraint: evidence from commercial rice farmers in Guangxi, China
}

\section{RESEARCH ARTICLE}

\author{
Xinjian Chen ${ }^{\oplus a}$, Di Zeng ${ }^{\mathrm{b}}$, Hui Zhang ${ }^{\mathrm{c}}$ and Chen Kang ${ }^{\mathrm{d}}$ \\ ${ }^{a}$ Associate professor, ${ }^{c}$ Research fellow, ${ }^{d}$ PhD student, Business School, Guangxi \\ University, 100 Daxue Road, Nanning 53004, China P.R. \\ ${ }^{b}$ Lecturer, The Centre for Global Food and Resources, The University \\ of Adelaide, Nexus 10, Adelaide 5005, Australia
}

\begin{abstract}
Agricultural production decisions in China are usually financially constrained, and the lack of credit often can prevent profitable investment such as farm expansion that generates economies of scale. However, farm expansion is still increasingly observed in China, where more smallholders are expanding farms towards moderate-scale operation, especially in the rice sector. This study investigates this paradox by specifically assessing the impact of credit constraint on farm expansion decisions using a representative household survey of rice farmers in Guangxi Province, China. Farm expansion is empirically measured by both actual expansion in the past five years and the willingness to expand in the near future, which is predicted by a series of factors where the possible endogeneity of credit constraint is accounted for using instrumental variable techniques. It is found that credit constraint negatively and significantly affects farm expansion. Such impact is heterogeneous and is larger among moderate scale holders. Our findings highlight the importance and necessity of offering financial services to relatively small-scale commercial farms in developing countries to relax their credit constraints.
\end{abstract}

Keywords: credit constrains, farm size, farm expand, rice farmer, China JEL code: Q12

\footnotetext{
(i)Corresponding author: xjchen@gxu.edu.cn
} 


\section{Introduction}

Food security is among the most important agricultural issues in China, where feeding a population of 1.38 billion has been consistently prioritized in agricultural policy designs (Godfray et al., 2010). While economies of scale usually stimulate agricultural productivity and thus increase farmer's income, for decades (Cao and Birchenall, 2013), the mismatch between a relatively large rural population and scarce arable land have allowed Chinese farm households (farmers hereafter) to operate on a landholding of only less than half hectare (Ostwald and Chen, 2006). On the one hand, farming at a too-small scale has inhibited the adoption of modern agricultural technology and the growth of farmers' income (Khataza et al., 2019). On the other hand, rising off-farm employment opportunities with urbanization, as well as increasing labor cost of farming, have further discouraged agricultural cultivation, especially for smallholders. As a result, land abandonment widely exists, with the remaining land being increasingly switched from staple to cash crops (Zhang et al., 2016), which lead great challenges to sustainable development of agriculture and potential enhancement of food security. In face to this change, the Chinese government has been promoting farm expansion through land transfer (of user rights) ${ }^{1}$ to carry out moderate-scale grain cultivation (Huang et al., 2017), which has gradually become a core component of China's agricultural policies in recent years (Chen, 2013). Encouragement from the government, along with the adoption of modern agricultural machinery, has stimulated moderate-scale grain cultivation in China (Huang and Ding, 2016). According to the decennial Agricultural Census of $\mathrm{China}^{2}$, the acreage cultivated by moderate-scale farmers and business entities ${ }^{3}$ account for $28.6 \%$ of the total cultivated area in China in 2016, and about $35 \%$ of the total farmland was transferred out, a huge increase from only $4.5 \%$ in 2006.

Realization of the economies of scale is subject to greater productive investment, especially in land and machinery (Wang et al., 2016). However, farmers in developing countries are often constrained by low income and credit constraint due to long-term relatively small scale farming and incomplete rural financial markets (Conning and Udry, 2007). Given its importance, production decisions under credit constraint are intensively studied (Barham et al., 1996; Boucher et al., 2008, 2009; Diagne et al., 2000; Jappelli, 1990). A growing empirical literature suggests that credit constraint has significant adverse effects on agricultural productivity (Guirkinger and Boucher, 2008; McIntosh et al., 2013), income (Boucher et al., 2008; Li and $\mathrm{Xi}, 2010$; Tran et al., 2016), technology adoption/investment (Berlinschi et al., 2014; Kumar et al., 2013; Okpukpara, 2010; Petrick, 2004; Porgo et al., 2018; Rao et al., 2014), and off-farm labor allocation (Porgo et al., 2018; Uchida et al., 2009). Researchers are commonly concerned about the reverse relationship between smallholders' farm size and productivity (Barrett, 1996; Fan and Chan-Kang, 2005; Feder, 1985; Helfand and Levine, 2004; Henderson, 2015), yet few have investigated the possible link between credit constraint and farm expansion. It is however important to quantify the impacts of credit constraint to assist future policy interventions that aim to strengthen the agricultural sector and help improve national food security through more profitable cultivation.

In rural China, financial markets are generally incomplete, and credit constraint is common among smallholders (Feder et al., 1990; Kumar et al., 2013; Li and Xi, 2010). The contrast between the widespread credit constraint and the noticeable farm expansion in the past decade therefore becomes a paradox to be investigated in the current study. Specifically, this paper aims to rigorously analyze the link between credit constraint and farm expansion in rural China using recent rice farm household survey in Guangxi province, China. To provide a comprehensive picture, past farm expansion decision and future expansion intention are parallelly analyzed. The possible endogeneity of expansion decision is addressed with instrumental variable techniques to obtain consistent estimates. Findings of this study will assist China's food security policy, production scale management, and rural financial reform as well as provide policy lessons to other developing countries.

\footnotetext{
${ }^{1}$ Land transfer in China concerns user rights only and occurs almost exclusively through land rental, as most land is collectively owned, according to the Property Law of the People's Republic of China passed in 2007.

${ }^{2}$ Third National Agriculture Census of China 2017. Available at: http://www.stats.gov.cn/tjsj/tjgb/nypcgb/ (in Chinese)

${ }^{3}$ Moderate-scale farmer and business entity: the farmer or entity cultivate more than 100 Chinese mu for single cropping or more than 50 Chinese $\mathrm{mu}$ in double season per year, $1 \mathrm{mu}=0.067$ hectare (ha).
} 
This article is organized as follows. Section two presents an analytical procedure. Section three describes data and summary statistics. Section four reports and discusses the empirical results. Section five finally concludes with policy implications.

\section{Analytical procedure}

To study the household farm expansion decision under credit constraint, it is necessary to first examine the existence of credit constraints among farmers. Following Diagne et al. (2000), Giné and Townsend (2004) and Boucher et al. $(2008,2009)$, the credit constraints is assessed using the direct elicitation approach. It carefully differentiates credit-constrained households from credit-unconstrained ones using self-reported credit demand in production activities. In the survey, farmers were asked about detailed loan needs, the reason(s) for either applying or not applying for loans, the amount of credit obtained and the reason(s) for not getting enough credit. To identify the existence of credit constraint, each farmer was asked whether he/she had a loan demand. Credit-unconstrained farmers are then identified as those who either had no credit demand or had such a demand but successfully secured the desired amount. In addition, farmers who listed the reasons for not applying credit such as high interest rate or repayment concerns are classified as an unconstrained as such demand was invalid (Boucher et al., 2009; Reyes and Lensink, 2011). Following Boucher et al. (2008), credit-constrained farmers include three categories: (1) quantity-rationed (those who applied but could not secure the desired amount of loan; (2) transaction-cost rationed (those with credit needs but failed to apply due to complex procedures, limited bank access, lack of social relationships, or unfamiliarity with loan application); and (3) risk-rationed (those who failed to apply in fear of losing collateral).

With appropriate identification of credit constraint among farmers, the next step is to assess the impact of credit constraint on farm expansion decision making. Apparently, such a decision is jointly affected by the household production and consumption characteristics as well as socio-economic characteristics in addition to credit constraint. While simple multiple regression models can help establish the links, they may suffer from possible endogeneity as the existence of credit constraint may be associated with unobserved characteristics (such as skills, experiences, entrepreneurial talents, risk attitudes, and social networks). This is highly likely since the factors affecting credit status can also affect scale farm operation decisions (Evans and Jovanovic, 1989; Giné and Townsend, 2004; Jappelli, 1990; Porgo et al., 2018), and such possible linkages can render regression estimation results biased and inconsistent. To correct for this, instrumental variable (IV) regressions are performed. At the farm household level, the conceptual model can be written as:

$$
E=\alpha+\beta C+\gamma X+\delta M+\theta L+\varepsilon
$$

In Equation 1, $E$ is a binary measure of farm expansion, which takes the value of one if the farmer decides to expand and zero otherwise. We further test the impact of credit constraint on rice areas expanded in 20132017 as a robustness exercise, and report the auxiliary regression estimates in the supplementary material. In empirical estimation, $E$ is measured in two alternative ways: whether the farmer has actually expanded farm size in the past five years, or whether he/she is willing to do so in the near future.

Among the independent variables, $C$ is a binary measure of credit constraint, one for credit-constrained farmers and zero for credit-unconstrained farmers. $X$ represents a set of demographic and socioeconomic characteristics that possibly affect farm expansion decision making. $M$ is a vector of local market condition indicators, including the number of local rice processing enterprises and the distance to the nearest grain wholesale market (measuring crop marketing easiness). In addition, $L$ is a landscape measure of the farm location (either in plain area or hilly and mountain area). $\alpha, \beta, \gamma, \delta$ and $\theta$ are coefficients representing the marginal effects of these factors on farm expansion decision to be estimated, and $\varepsilon$ is the random disturbance.

To account for the possible endogeneity of credit constraint, IV regression is performed, where the first-stage regression model is specified as: 


$$
C=a+b D+c N+d X+f M+g L+u
$$

To estimate Equation 2, two IVs are employed: the distance to the nearest financial institution $(D)$, and the number of local financial institutions within 30 kilometers from the respondent's residence $(N)$. Other covariates are described above. $a, b, c, d, f, g$ are coefficients to be estimated, and $u$ is the disturbance. It can be intuitively justified that both IVs should be correlated with the existence of credit constraint but should not directly affect farm expansion decision other than through their impact on the farmer's credit status. Much of Guangxi is of a karst topography characterized by cone-like mountains and flat areas in between. Unlike some other regions in China, most of these mountains are too steep to construct rice terraces. Hence, rice cultivation is largely concentrated in flat areas, where township centers are usually located. In those flat areas, farmers' land plots are usually connected with similar land quality and agroecological conditions. Therefore, few townships are too remote to access financial services. On the other hand, the Chinese government has been endeavoring to provide credit access to every single township in hope of removing credit constraints among the neediest members in rural areas. Consequently, there are usually at least two or three financial institutions in every township center (mainly Agricultural Bank of China, Rural Credit Cooperatives, and Postal Savings Bank of China). There is also variation in the number of financial institutions according to population size and industrial developmental stage. But no township is too remote to access finance as a distance of 30 kilometers is large enough to allow such access (even from nearby townships). Therefore, concerns over the validity of the distance-based IVs for credit constraint should be minimized. Empirical tests further reveal that these IVs are appropriate in identifying the hypothesized relationship, as discussed in detail below.

\section{Data and descriptive statistics}

\subsection{Data}

Guangxi is one major region in China for double-season rice planting, which has a long history of rice cultivation and is the origin of human rice culture (Huang et al., 2012). The current study is facilitated by a recent rural household survey conducted by the academic staff members and graduate students of Guangxi University from July 2016 to April 2017. The survey covered six regions: Nanning, Guilin, Liuzhou, Guigang, Yulin and Qinzhou, which jointly contribute about $70 \%$ rice production of the whole province. Stratified sampling approach was used in the survey. Within these six regions, 15 counties were first selected according to the aggregate rice cultivation area in the past four years (2013-2016). Three townships were then randomly selected in each county, and twelve rice farmers were randomly selected from each township. As the focus of the survey is rice farm size and scale operation, the surveyed households selected in these samples have met the following conditions: (1) rice is grown for commercial markets rather than mere self-sufficiency; and (2) rice cultivation is one of the main sources of household income. Farmers who planted rice on a moderately large scale were still few in rural Guangxi, especially those who planted more than $50 \mathrm{mu}$ (3.33 ha) of land. Compared with developed countries, the farm size of the sampled farmers in this paper is relatively small, but compared with those subsistence farmers, farm sizes of sampled households are larger. A total of 540 rice households were randomly selected in 45 townships, of which $462(85.6 \%)$ were at home at the time of survey and all of them participated. Among the 78 absentees, we contacted them later through telephone and accessed 48 of them. The observed characteristics, namely values of variables included in the following analysis, were very similar to those of face-to-face respondents (with no statistical significance at 5\% level through pairwise t-tests). Concerns over sample selection is thus minimized.

\subsection{Descriptive statistics}

The distribution of credit constraint among surveyed farmers in Guangxi is presented in Table 1. 42.86\% of the farmers were credit constrained while $57.14 \%$ were unconstrained, jointly manifesting a relatively large data variation. About half of the unconstrained farmers exhibit invalid demand for credit, while only less than one fifth of the farmers in need of credit have successfully secured the needed amount. Most creditconstrained farmers are quantity rationed, failing to obtain the desired amount. 
Table 1. Credit constraint distribution among surveyed households $(\mathrm{n}=462)$.

\begin{tabular}{lcc}
\hline Credit status & Frequency & Percentage \\
\hline Unconstrained & 264 & 57.14 \\
No need for credit & 116 & 25.11 \\
Could obtain enough credit & 31 & 6.71 \\
No application due to high interest rate & 60 & 12.99 \\
No application due to repayment concerns & 57 & 12.34 \\
Constrained & 198 & 42.86 \\
Quantity rationed & 121 & 26.19 \\
Transaction-cost rationed & 65 & 14.07 \\
Risk rationed & 12 & 2.60 \\
\hline
\end{tabular}

Farm size changes in 2013-2017 are reported in Table 2. About $31.38 \%$ of the total households remained at the same size, while $61.04 \%$ households increased and $7.57 \%$ decreased their rice farm size over the five years. On the one hand, about half of the credit constrained households increased their farm size, whereas $69.69 \%$ of the credit unconstrained households increased. On the other hand, $15.15 \%$ of credit constrained households decreased their rice farm size while just $1.89 \%$ of credit unconstrained households decreased over the five years.

Table 3 describes the outcome variables and covariates. About $61 \%$ households expanded their farm in the past five years and half of the farmers were willing to expand their rice farm size in the near future. Other observations include the low education rate ( 7.67 years on average) and the importance of on-farm income generation ( $82 \%$ of family income). In addition, $39 \%$ of the surveyed farmers had obtained credit from informal sources (e.g. friends, relatives, inputs suppliers).

\section{Results and discussions}

The empirical analysis proceeds as follows. With two alternative measures of farm expansion, the impact of credit constraint on expansion decisions in the past five years is first estimated, and then is the impact on the willingness of farm expansion in the near future. The possibly impacts on relatively larger ( $\geq 3.33 \mathrm{ha})$ and smaller holders ( $<3.33 \mathrm{ha})$ are further differentiated and compared.

Given the binary nature of the outcome variable, a probit model is first estimated. To address possible endogeneity of the credit constraint, an IV-probit model is also estimated. The same regression model is further estimated using two-stage least squares (2SLS). 2SLS is suitable as it is robust against first-stage misspecifications and it usually provides very close marginal effect estimates as compared to discrete choice models (Angrist, 2001; Angrist and Pischke, 2008). It thus serves as a reliable robustness check exercise. The first-stage results of 2SLS estimation as shown in Supplementary Table S1 rules out instrument weakness. Moreover, farmers who are farther away from the financial institutions and who have access to fewer financial institutions are more likely to have credit constraint, yet these two variables have negligible effect on the farm size. These findings consistently suggest the appropriateness of the IVs. In estimation, standard errors are clustered at township level.

Table 2. Farm size changes in 2013-2017: number of farmers (\% of total).

Full sample $(n=462) \quad$ Credit-constrained $(n=198) \quad$ Credit-unconstrained $(n=264)$

\begin{tabular}{lccc}
\hline Increasing (expanded) & $282(61.04 \%)$ & $98(49.49 \%)$ & $184(69.69 \%)$ \\
Constant & $145(31.38 \%)$ & $70(35.35 \%)$ & $75(28.41 \%)$ \\
Decreasing & $35(7.57 \%)$ & $30(15.15 \%)$ & $5(1.89 \%)$ \\
\hline
\end{tabular}


Table 3. Descriptive statistics of variables. ${ }^{\mathrm{a}}$

\begin{tabular}{|c|c|c|c|}
\hline Variables & $\begin{array}{l}\text { Full sample } \\
(n=462)\end{array}$ & $\begin{array}{l}\text { Credit-constrained } \\
(n=198)\end{array}$ & $\begin{array}{l}\text { Credit-unconstrained } \\
(n=264)\end{array}$ \\
\hline Farm expanded past five years $(\mathrm{yes}=1 ; \mathrm{no}=0)$ & $0.61(0.48)$ & $0.49^{* * *}(0.50)$ & $0.69(0.46)$ \\
\hline Willing to expand in the future (yes $=1 ; \mathrm{no}=0$ ) & $0.47(0.49)$ & $0.26^{* * *}(0.44)$ & $0.64(0.48)$ \\
\hline Rice cultivation area in 2013 (ha) & $3.94(8.06)$ & $5.02^{* * *}(9.98)$ & $3.14(6.14)$ \\
\hline Rice cultivation area in 2017 (ha) & $6.12(11.83)$ & $7.04^{*}(15.32)$ & $5.43(8.27)$ \\
\hline Credit constrained $($ yes $=1 ;$ no $=0)$ & $0.43(0.49)$ & $1.00(0.00)$ & $0.00(0.00)$ \\
\hline Head age (years) & $49.03(8.73)$ & $49.31(9.19)$ & $48.82(8.37)$ \\
\hline Head gender $($ male $=1$; female $=0)$ & $0.92(0.27)$ & $0.93(0.25)$ & $0.91(0.28)$ \\
\hline Head education (years) & $7.67(2.59)$ & $7.46^{*}(2.54)$ & $7.81(2.63)$ \\
\hline Family income ${ }^{b}$ (4-year average, logarithmic) & $3.78(0.97)$ & $3.73(1.04)$ & $3.82(0.92)$ \\
\hline Off-farm income share (4-year average) & $0.18(0.25)$ & $0.15^{* *}(0.22)$ & $0.20(0.26)$ \\
\hline Number of family laborers & $2.27(1.15)$ & $2.25(1.16)$ & $2.28(1.13)$ \\
\hline Number of dependents in household & $1.42(1.32)$ & $1.47(1.36)$ & $1.37(1.29)$ \\
\hline Farmer cooperative member $($ yes $=1 ;$ no $=0)$ & $0.34(0.48)$ & $0.57^{* * *}(0.49)$ & $0.17(0.37)$ \\
\hline $\begin{array}{l}\text { Times of mechanical service from others } \\
(\text { never }=0 \text {, once }=1 \text {, twice }=2 \text { ) }\end{array}$ & $1.19(0.72)$ & $1.62^{* * *}(0.61)$ & $0.87(0.62)$ \\
\hline Informal source of $\operatorname{credit}^{\mathrm{c}}(\mathrm{yes}=1 ;$ no $=0)$ & $0.39(0.48)$ & $0.67^{* * *}(0.47)$ & $0.18(0.38)$ \\
\hline Number of processing enterprises & $1.53(1.28)$ & $2.27^{* * *}(1.27)$ & $0.97(0.96)$ \\
\hline Distance to wholesale market $(\mathrm{km})$ & $38.21(20.18)$ & $39.04(20.24)$ & $37.58(20.14)$ \\
\hline Flat area $($ yes $=1 ;$ no $=0)$ & $0.69(0.46)$ & $0.66^{*}(0.47)$ & $0.72(0.45)$ \\
\hline
\end{tabular}

\subsection{Effects of credit constraint on famers'farm expansion in the past five years}

Table 4 represents the estimation results where farm expansion is measured in such decision made in the past five years. Computed marginal effects from the IV-probit and coefficient estimates from the 2SLS procedures are reassuringly similar, lending credence to the impact estimates. In all models, credit constraint is found to be negatively associated with farm expansion decision, such impact being highly significant. Specifically, the existence of credit constraint decreases the probability of rice farm size expansion by 37.340.4 percentage points. It is therefore implied that farm expansion would be encouraged once the credit constraint is removed, and economies of scale can be better realized among these rice farmers. On the other hand, the initial rice cultivation area in the past five years (as that of 2013) is also found to play a negative role in farm expansion: larger farms are less likely to expand. While such impact is relatively small, it does imply that there may be some systematic linkage between farm size and expansion decision.

Although credit constraint discourages farm expansion, the general pattern observed in China is that farm sizes are still growing. Thus, there is a need to interpret the possible roles that other factors play to understand the paradox. Among the covariates, farm expansion is more likely among richer farmers, having more dependents and located in flat areas. In production practices, farm expansion is associated with utilization of specialized mechanical service and informal credit. These individual impacts, however, are smaller in magnitude as compared to that of credit constraint.

Supplemetary Table S2 further reports regression results using actual farm expansion in 2013-2017 as the outcome variable. These estimates appear to be very similar to our main results above, with impact magnitudes of credit constraint being larger. The above findings are therefore well supported. 
Table 4. Marginal effects on household's farm size expansion in 2013-2017. ${ }^{\mathrm{a}}$

\begin{tabular}{llll}
\hline Covariate & Probit & IV Probit & 2SLS \\
\hline Credit constraint & $-0.404^{* * *}(0.042)$ & $-0.440^{* * *}(0.049)$ & $-0.373^{* * * *}(0.053)$ \\
Rice cultivation area (2013) & $-0.011^{* * *}(0.004)$ & $-0.010^{* * *}(0.004)$ & $-0.012^{* * *}(0.004)$ \\
Head age & $0.001(0.002)$ & $0.001(0.002)$ & $0.001(0.002)$ \\
Head gender & $-0.071(0.056)$ & $-0.070(0.055)$ & $-0.079(0.064)$ \\
Head education & $0.019^{* *}(0.008)$ & $0.017^{* *}(0.008)$ & $0.019^{* *}(0.009)$ \\
Family income (in logarithm) & $0.126^{* * *}(0.026)$ & $0.122^{* * *}(0.027)$ & $0.118^{* * *}(0.029)$ \\
\% off-farm income & $-0.089(0.078)$ & $-0.094(0.077)$ & $-0.077(0.087)$ \\
Number of family laborers & $0.014(0.018)$ & $0.014(0.017)$ & $0.018(0.018)$ \\
Number of dependents & $0.055^{* * *}(0.015)$ & $0.053^{* * *}(0.015)$ & $0.054^{* * *}(0.015)$ \\
Cooperative membership & $0.075(0.047)$ & $0.082(0.049)$ & $0.087(0.052)$ \\
Mechanical service & $0.101^{* * * *}(0.035)$ & $0.107^{* * *}(0.035)$ & $0.083^{* *}(0.033)$ \\
Informal credit & $0.195^{* * *}(0.060)$ & $0.202^{* * *}(0.059)$ & $0.180^{* * *}(0.062)$ \\
Number of enterprises & $0.010(0.025)$ & $0.014(0.024)$ & $0.003(0.024)$ \\
Distance to wholesale market & $-0.001(0.001)$ & $-0.001(0.001)$ & $-0.000(0.001)$ \\
Flat area & $0.086^{* *}(0.038)$ & $0.081^{* *}(0.039)$ & $0.111^{* *}(0.049)$ \\
Observations & 462 & 462 & 462 \\
Wald chi ${ }^{2}(15)$ & $232.7^{* * *}(0.000)$ & $237.2^{* * *}(0.000)$ & \\
F-statistic for IV significance & & & $222.61^{* * *}(0.000)$ \\
F-statistic $\left(2^{\text {nd }}\right.$ stage) & & & $50.52^{* * *}(0.000)$
\end{tabular}

a Standard errors are clustered at township level and reported in parentheses. ${ }^{* *},{ }^{* *},{ }^{*}$ indicate 1,5 and $10 \%$ significance, respectively. Marginal effects reported in Probit and IV-Probit model, while coefficient estimates reported in 2SLS model.

\subsection{Impact of credit constraint on farmers' willingness of farm expansion}

The impact of credit constraint on farmers' willingness of farm expansion is further estimated (Table 5). Impact estimates from IV-probit and 2SLS are also reasonably similar in magnitude as well as 1\% significance. Specifically, credit constraint negatively affects farm expansion willingness. The impact is 56.7-65.9 percentage points, which is larger than that on observed farm expansion in the past five years. Current rice cultivation area is again negatively affecting farm expansion willingness.

Among the covariate coefficients, age and gender become statistically significant, which contrast the above findings with actual farm expansion measure. Intuitively, older and female farmers are less willing to expand farm, though such patterns are inexistent among the farmers who have actually expanded farms in the past five years. In addition, larger off-farm income contribution also discourages farm expansion, while membership of farmer cooperative encourages it possibly due to better access to production and/or risk-mitigating resources, and/or marketing opportunities (Liu et al., 2019). The impacts of education and family size (number of dependents) are again confirmed. While the role of informal credit is not well supported (as the coefficient is statistically insignificant in 2SLS estimation), this is possible as farmers with only willingness to expand farms might not utilize these resources and so such impact has not been noticeable. A further discrepancy exists regarding mechanical service utilization, the impact of which becomes insignificant on farmers' willingness of farm expansion. This can be possibly explained by the fact that third-party mechanical service could become unaffordable with farm size expansion for a significant portion of farmers. 
Table 5. Marginal effects on household's willingness to farm expand in the future. ${ }^{\mathrm{a}}$

\begin{tabular}{llll}
\hline Variable & Probit & IV Probit & 2SLS \\
\hline Credit constraint & $-0.589^{* * *}(0.054)$ & $-0.659^{* * *}(0.063)$ & $-0.567^{* * *}(0.049)$ \\
Rice cultivation area (2017) & $-0.008^{* * *}(0.002)$ & $-0.007^{* * *}(0.003)$ & $-0.006^{* * *}(0.002)$ \\
Head age & $-0.012^{* * *}(0.002)$ & $-0.012^{* * *}(0.002)$ & $-0.014^{* * *}(0.002)$ \\
Head gender & $0.132^{* * *}(0.049)$ & $0.128^{* * *}(0.048)$ & $0.145^{* *}(0.057)$ \\
Head education & $0.039^{* * *}(0.008)$ & $0.035^{* * *}(0.009)$ & $0.045^{* * *}(0.009)$ \\
Family income (in logarithm) & $0.019(0.032)$ & $0.013(0.031)$ & $0.006(0.032)$ \\
\% off-farm income & $-0.147^{* *}(0.061)$ & $-0.158^{* * *}(0.061)$ & $-0.197^{* * *}(0.075)$ \\
Family laborers & $0.016(0.013)$ & $0.015(0.013)$ & $0.014(0.016)$ \\
Number of dependents & $0.037^{* * *}(0.012)$ & $0.033^{* *}(0.013)$ & $0.031^{* *}(0.013)$ \\
Cooperative membership & $0.152^{* * *}(0.052)$ & $0.166^{* * *}(0.052)$ & $0.104^{* * *}(0.035)$ \\
Mechanical service & $0.032(0.031)$ & $0.043(0.031)$ & $0.034(0.029)$ \\
Informal credit & $0.105^{* *}(0.050)$ & $0.124^{* *}(0.052)$ & $0.072(0.045)$ \\
Number of enterprises & $0.048^{* * *}(0.018)$ & $0.056^{* * *}(0.018)$ & $0.036^{*}(0.020)$ \\
Distance to wholesale market & $0.001(0.001)$ & $0.000(0.001)$ & $0.000(0.001)$ \\
Flat area & $0.052(0.043)$ & $0.044(0.044)$ & $0.052(0.047)$ \\
Observations & 462 & 462 & 462 \\
Wald chi ${ }^{2}(15)$ & $269.6^{* * *}(0.000)$ & $296.4^{* * *}(0.000)$ & \\
F-statistic for IV significance & & & $224.54^{* * *}(0.000)$ \\
F-statistic $\left(2^{\text {nd }}\right.$ stage) & & & $75.69^{* * *}(0.000)$
\end{tabular}

a Standard errors are clustered at township level and reported in parentheses. ${ }^{* * *},{ }^{* *},{ }^{*}$ indicate 1,5 and $10 \%$ significance, respectively. Marginal effects reported in Probit and IV-Probit model, while coefficient estimates reported in 2SLS model.

\subsection{Robust checks}

In the above analysis, family income and utilization of mechanical service could be an outcome of farmers' farm expansion decision, which may introduce a reverse causality problem. Also, rice cultivated area may have non-linear effects. To explicitly address these concerns, we implement robustness checks by adding or removing the explanatory variables. Results are reported in Table 6.

As shown in Table 6, the first column is the regression result after removing the family income variable in the model. The second column is the regression result after removing the mechanical service variable. And the third column is the regression result after adding the square of the rice cultivation area. Computed marginal effects from the IV-probit and coefficient estimates from the 2SLS procedures show that there are no noticeable differences in the estimated marginal effects of credit constraint on the actual farm expansion decision and willingness of farm expansion in the future. The changes of control variables in the estimates have little impact on the estimated results, and the credit constraint is negative and very significant in all the models. For the focus of the impact of credit constraints, these estimates are robust and lend credence to our main results.

\subsection{Impacts of credit constraint on relatively smaller and larger farmers' expansion}

Results from both measures (actual decision and willingness of farm expansion) suggest that farm size can play a role, and that the impact of credit constraint may differ between relatively smaller $(<3.33 \mathrm{ha})$ and larger ( $\geq 3.33 \mathrm{ha}$ ) commercial farmers. It is therefore straightforward to implement two subsample analyses to break down the possible heterogeneity. This is meaningful to policymakers regarding the necessity to differentiate interventions by landholding to maximize the desired effect. Results are reported in Table 7. 
Table 6. Robust checking estimates with alternative covariate sets. ${ }^{\mathrm{a}}$

\begin{tabular}{|c|c|c|c|c|c|c|}
\hline \multirow[t]{2}{*}{ Covariate change } & \multicolumn{2}{|c|}{$\begin{array}{l}\text { Excluding family } \\
\text { income }\end{array}$} & \multicolumn{2}{|c|}{$\begin{array}{l}\text { Excluding mechanical } \\
\text { service }\end{array}$} & \multicolumn{2}{|c|}{$\begin{array}{l}\text { Adding square term of rice } \\
\text { cultivation area }\end{array}$} \\
\hline & IV Probit & 2SLS & IV Probit & 2SLS & IV Probit & 2SLS \\
\hline \multicolumn{7}{|l|}{ Farm size expanded } \\
\hline Coef. of credit constraint & $\begin{array}{l}-1.798^{* * *} \\
(0.234)\end{array}$ & $\begin{array}{l}-0.403^{* * *} \\
(0.052)\end{array}$ & $\begin{array}{l}-1.524^{* * *} \\
(0.250)\end{array}$ & $\begin{array}{l}-0.342^{* * *} \\
(0.054)\end{array}$ & $\begin{array}{l}-1.691^{* * *} \\
(0.264)\end{array}$ & $\begin{array}{l}-0.351^{* * *} \\
(0.051)\end{array}$ \\
\hline Marginal effects & $\begin{array}{l}-0.402^{* * *} \\
(0.053)\end{array}$ & & $\begin{array}{l}-0.327^{* * *} \\
(0.056)\end{array}$ & & $\begin{array}{l}-0.334^{* * *} \\
(0.053)\end{array}$ & \\
\hline Wald chi $^{2}$ & $\begin{array}{l}186.8^{* * *} \\
(0.000)\end{array}$ & & $\begin{array}{l}227.1^{* * *} \\
(0.000)\end{array}$ & & $\begin{array}{l}206.7^{* * *} \\
(0.000)\end{array}$ & \\
\hline F-value ( $1^{\text {st }}$ stage $)$ & & $\begin{array}{l}214.5^{* * *} \\
(0.000)\end{array}$ & & $\begin{array}{l}264.3^{* * *} \\
(0.000)\end{array}$ & & $\begin{array}{l}218.7^{* * *} \\
(0.000)\end{array}$ \\
\hline \multicolumn{7}{|l|}{ Willingness to expand } \\
\hline Coef. of credit constraint & $\begin{array}{l}-3.102^{* * *} \\
(0.303)\end{array}$ & $\begin{array}{l}-0.567^{* * *} \\
(0.049)\end{array}$ & $\begin{array}{l}-2.991^{* * *} \\
(0.285)\end{array}$ & $\begin{array}{l}-0.554^{* * *} \\
(0.046)\end{array}$ & $\begin{array}{l}-3.146^{* * *} \\
(0.310)\end{array}$ & $\begin{array}{l}-0.570^{* * *} \\
(0.049)\end{array}$ \\
\hline Marginal effects & $\begin{array}{l}-0.511^{* * *} \\
(0.062)\end{array}$ & & $\begin{array}{l}-0.490^{* * *} \\
(0.057)\end{array}$ & & $\begin{array}{l}-0.513^{* * *} \\
(0.064)\end{array}$ & \\
\hline Wald chi $^{2}$ & $\begin{array}{l}266.3^{* * *} \\
(0.000)\end{array}$ & & $\begin{array}{l}278.6^{* * *} \\
(0.000)\end{array}$ & & $\begin{array}{l}312.9^{* * *} \\
(0.000)\end{array}$ & \\
\hline F-value ( $1^{\text {st }}$ stage $)$ & & $\begin{array}{l}217.2^{* * *} \\
(0.000)\end{array}$ & & $\begin{array}{l}268.0^{* * *} \\
(0.000)\end{array}$ & & $\begin{array}{l}226.2^{* * *} \\
(0.000)\end{array}$ \\
\hline
\end{tabular}

Table 7. Subsample impact estimates by farm size. ${ }^{a, b}$

\begin{tabular}{|c|c|c|c|c|}
\hline \multirow[t]{2}{*}{ Variable } & \multicolumn{2}{|l|}{ Larger holders } & \multicolumn{2}{|l|}{ Smaller holders } \\
\hline & IV Probit & 2SLS & IV Probit & 2SLS \\
\hline Farm size expanded ${ }^{c}$ & $\mathrm{n}=113$ & & $n=349$ & \\
\hline Coef. of credit constraint & $-3.084^{* * *}(1.031)$ & $-0.471^{* * *}(0.084)$ & $-1.586^{* * *}(0.365)$ & $-0.296^{* * *}(0.079)$ \\
\hline Marginal effects & $-0.593^{* * *}(0.151)$ & & $-0.381^{* * *}(0.092)$ & \\
\hline Wald chi ${ }^{2}$ & $47.83^{* * *}(0.000)$ & & $98.90^{* * *}(0.000)$ & \\
\hline F-value ( $1^{\text {st }}$ stage $)$ & & $98.70^{* * *}(0.000)$ & & $94.11^{* * *}(0.000)$ \\
\hline Willingness to expand ${ }^{d}$ & $n=207$ & & $n=255$ & \\
\hline Coef. of credit constraint & $-3.482^{* * *}(0.695)$ & $-0.617^{* * *}(0.067)$ & $-2.648^{* * *}(0.467)$ & $-0.444^{* * *}(0.078)$ \\
\hline Marginal effects & $-0.654^{* * *}(0.105)$ & & $-0.487^{* * *}(0.082)$ & \\
\hline Wald chi ${ }^{2}$ & $56.05^{* * *}(0.000)$ & & $71.68^{* * *}(0.000)$ & \\
\hline F-value ( $1^{\text {st }}$ stage $)$ & & $77.51^{* * *}(0.000)$ & & $129.1^{* * *}(0.000)$ \\
\hline
\end{tabular}

As reported in Table 7, there are noticeable differences in the estimated marginal effects of credit constraint on the actual farm expansion decision and willingness of farm expansion in the future. Specifically, the marginal effects in IV-probit models and the coefficient estimates in 2SLS models appear to be bigger for large holders (i.e. the impact is bigger for large holders). Therefore, when the smaller holders grow into moderate farmers with a size of $50 \mathrm{mu}(3.33 \mathrm{ha})$ or more, householders will be more vulnerable to credit constraints, 
and it will be even more difficult to expand farm size/scale. Hence, moderate farmers may deserve specific attention in policy designs that aim to optimize the production scale and improve the credit market conditions.

The above findings generally suggest that credit constraints impede farm expansion. The negative impacts, however, might have been totally offset by positive contributions of other covariates, and thus farm expansion is still commonly observed. This helps explain the paradox where credit constraints and farm expansion are both widely observed and suggests that removal of credit constraints can further facilitate farm expansion.

\section{Conclusions and policy implications}

Using a recent survey of commercial rice farmers in Guangxi Province, China, this study empirically assesses the impact of credit constraint on farm expansion to investigate the paradox where credit constraints and farm expansions coexist. As hypothesized, credit constraint significantly discourages farm expansion decision, as measured by both actual expansion decision and the willingness. Moreover, subsample analysis further suggests that, while the impacts of credit constraint on farm expansion are similar between relatively small and moderate scale holders, moderate farmers are more susceptible to credit constraint both in actual expansion decision and such willingness in future. This finding contributes to the literature on the multifaceted disadvantages of smaller holders in farm expansion and their consequences (Collier and Dercon, 2014; Huang and Ding, 2016; Ostwald and Chen, 2006), and points to a need for tailored policy considerations (Huber et al., 2015). While the negative impacts of credit constraint on farm expansion are offset by resources available otherwise (e.g. informal credit, third-party mechanical service, and cooperative membership), further farm expansion and better realization of the economies of scale still rely on credit constraint removal.

Given the immediate impact estimated above, it should be among the government's policy considerations to further develop the credit market with a focus on the provision of microfinance to householders. First, the role of informal credit access clearly points to the importance of having a variety of available credit options to meet different credit needs. Hence, encouraging the development of micro financial institutions and informal agricultural financial institutions will be beneficial in relaxing credit constraints on farmers. Second, as smaller holders generally lack collateral, credit constraint cannot be completely removed in the short term. On the one hand, interventions may alternatively focus on the stabilization of rural household income, through the mitigation of possible production and/or marketing risks, to facilitate continuous income growth and increases in capital investment. On the other hand, the ongoing gradual reform of the rural land system can also increase the liquidity of farmers' land and thus facilitate land mortgage with the rural financial institution. Third, provision of mechanical and related agricultural services can also lower the investment of farmers and stimulate scale operation.

Policy implications can be then drawn for the credit supply side, namely agricultural credit institutions. With the expansion of agricultural operation scale, the fact that nearly half of the $(42.86 \%)$ surveyed farmers were credit constrained suggests that the rural financial market huge potential given the substantial demand. Therefore, credit institutions should pay attention to services and financial instrument innovations to meet farmers' needs. In addition, policies seeking the development of rural financial business, rural financial institutions could rigorously study the feasibility of issuing micro-credit to more smaller farmers and provide more financial services to large farmers with the help of modern information technology more efficiently assessing farmers' credit ratings and collateral values. Last but not the least, rural financial institutions may invest more marketing efforts, and make it easier for farmers to grow their knowledge of available financial products as transaction cost rationed is an important reason for farmers' credit constraint.

There are also policy implications for the credit demand side respect to farm and agribusiness management. First, farms should carry out necessary risk management strategies (such as purchasing agricultural insurance and diversifying product portfolio) to smooth farm income maintains good credit history, which can help minimize financial providers' concerns over repayment risk. Second, farms should seek to participate in relevant financial trainings or market activities many times carried out as parts of extension packages and 
keep communication with financial institutions so as to reduce information asymmetry. Third, smaller-scale farms can cooperate with each other and support each other in terms of credit through farm cooperatives or associations, especially in mutual borrowing. While validating the merits of these policies is beyond the scope of this analysis, they are worth policy considerations, which is especially important in enhancing food security in countries like China.

For individual farms, the potential use of credit also needs improvement. It should be noted that farm management practices in China may differ from those in developed countries. Chinese farmers still emphasize the production process while largely overlook value chain development and marketing. In smaller scale farming, farmers will purchase third-party services in some production links to ease the financial constraints (such as mechanical services). With available credit, farmers may use the credit to invest machinery and equipment, but usually fail to investment in value chain cooperation, talent development and marketing. This perceptual myopia may arise from the tradition of subsistence agriculture and need to be corrected for sustainable farm management. This is especially important to China, which is transitioning from smallholder rural economy to commercialized agriculture.

The current study observes limitations. For one thing, the cross-sectional nature of data cannot fully capture farmland dynamics over time. For another, the specific geographical focus (one major rice-cultivating region) may not represent situations observed in other parts of China or different countries. These limitations jointly call for further investigations and research to help establish the external validity of our findings.

\section{Supplementary material}

Supplementary material can be found online at https://doi.org/10.22434/IFAMR2019.0118

Table S1. First stage regression estimation of 2SLS model.

Table S2. Regression results of farm size changes in 2013-2017.

\section{Acknowledgements}

The authors are grateful to National Natural Sciences Foundation of China (71663008), the Ministry of Education of Humanities and Social Science project (16XJC790002), the Natural Sciences Foundation of Guangxi Province (2015GXNSFBA139092) and Guangxi Development Strategy Institute (Key project 2019) for financial support for this study.

\section{References}

Angrist, J.D. 2001. Estimation of limited dependent variable models with dummy endogenous regressors: simple strategies for empirical practice. Journal of Business \& Economic Statistics 19(1): 2-28.

Angrist, J.D. and J.-S. Pischke. 2008. Mostly harmless econometrics: an empiricist's companion. Princeton University Press, Princeton, NJ, USA.

Barham, B.L., S. Boucher and M.R. Carter. 1996. Credit constraints, credit unions, and small-scale producers in Guatemala. World Development 24(5): 793-806.

Barrett, C.B. 1996. On price risk and the inverse farm size-productivity relationship. Journal of Development Economics 51(2): 193-215.

Berlinschi, R., J. Swinnen and K. Van Herck. 2014. Trapped in agriculture? Credit constraints, investments in education and agricultural employment. European Journal of Development Research 26(4): 490-508.

Boucher, S.R., M.R. Carter and C. Guirkinger. 2008. Risk rationing and wealth effects in credit markets: theory and implications for agricultural development. American Journal of Agricultural Economics 90(2): 409-423. 
Boucher, S.R., C. Guirkinger and C. Trivelli. 2009. Direct elicitation of credit constraints: conceptual and practical issues with an application to Peruvian agriculture. Economic Development and Cultural Change 57(4): 609-640.

Cao, K.H. and J.A. Birchenall. 2013. Agricultural productivity, structural change, and economic growth in post-reform China. Journal of Development Economics 104: 165-180.

Chen, X. 2013. Accelerate the development of modern agriculture by new type of agricultural management system. Economic Research Journal 2: 4-6. (in Chinese)

Collier, P. and S. Dercon. 2014. African agriculture in 50 years: smallholders in a rapidly changing world? World Development 63: 92-101.

Conning, J. and C. Udry. 2007. Rural financial markets in developing countries. Handbook of Agricultural Economics 3: 2857-2908.

Diagne, A., M. Zeller and M. Sharma. 2000. Empirical measurements of households' access to credit and credit constraints in developing countries: methodological issues and evidence. International Food Policy Research Institute, Washington, DC, USA.

Evans, D.S. and B. Jovanovic. 1989. An estimated model of entrepreneurial choice under liquidity constraints. Journal of Political Economy 97(4): 808-827.

Fan, S. and C. Chan-Kang. 2005. Is small beautiful? Farm size, productivity, and poverty in Asian agriculture. Agricultural Economics 32(s1): 135-146.

Feder, G. 1985. The relation between farm size and farm productivity: the role of family labor, supervision and credit constraints. Journal of Development Economics 18(2-3): 297-313.

Feder, G., L.J. Lau, J.Y. Lin and X. Luo. 1990. The relationship between credit and productivity in Chinese agriculture: a microeconomic model of disequilibrium. American Journal of Agricultural Economics 72(5): 1151-1157.

Giné, X. and R.M. Townsend. 2004. Evaluation of financial liberalization: a general equilibrium model with constrained occupation choice. Journal of Development Economics 74(2): 269-307.

Godfray, H.C.J., J.R. Beddington, I.R. Crute, L. Haddad, D. Lawrence, J.F. Muir, J. Pretty, S. Robinson, S.M. Thomas and C. Toulmin. 2010. Food security: the challenge of feeding 9 billion people. Science 327(5967): 812-818.

Guirkinger, C. and S.R. Boucher. 2008. Credit constraints and productivity in Peruvian agriculture. Agricultural Economics 39(3): 295-308.

Helfand, S.M. and E.S. Levine. 2004. Farm size and the determinants of productive efficiency in the Brazilian Center-West. Agricultural Economics 31(2-3): 241-249.

Henderson, H. 2015. Considering technical and allocative efficiency in the inverse farm size-productivity relationship. Journal of Agricultural Economics 66(2): 442-469.

Huang, J. and J. Ding. 2016. Institutional innovation and policy support to facilitate small-scale farming transformation in China. Agricultural Economics 47(S1): 227-237.

Huang, X., N. Kurata, Z.-X. Wang, A. Wang, Q. Zhao, Y. Zhao, K. Liu, H. Lu, W. Li and Y. Guo. 2012. A map of rice genome variation reveals the origin of cultivated rice. Nature 490(7421): 497-501.

Huang, Z., L. Guan and S. Jin. 2017. Scale farming operations in China. International Food and Agribusiness Management Review 20(2): 191-200.

Huber, R., C. Flury and R. Finger. 2015. Factors affecting farm growth intentions of family farms in mountain regions: empirical evidence for Central Switzerland. Land Use Policy 47: 188-197.

Jappelli, T. 1990. Who is credit constrained in the US economy? Quarterly Journal of Economics 105(1): 219-234.

Khataza, R.R.B., A. Hailu, G.J. Doole, M.E. Kragt and A.D. Alene. 2019. Examining the relationship between farm size and productive efficiency: a Bayesian directional distance function approach. Agricultural Economics 50(2): 237-246.

Kumar, C.S., C.G. Turvey and J.D. Kropp. 2013. The impact of credit constraints on farm households: survey results from India and China. Applied Economic Perspectives and Policy 35(3): 508-527.

Li, R. and Z. Xi. 2010. Econometric analysis of credit constraints of Chinese rural households and welfare loss. Applied Economics 42(13): 1615-1625. 
Liu, Y., W. Ma, A. Renwick and X. Fu. 2019. The role of agricultural cooperatives in serving as a marketing channel: evidence from low-income regions of Sichuan province in China. International Food and Agribusiness Management Review 22(2): 265-282.

McIntosh, C., A. Sarris and F. Papadopoulos. 2013. Productivity, credit, risk, and the demand for weather index insurance in smallholder agriculture in Ethiopia. Agricultural Economics 44(4-5): 399-417.

Okpukpara, B. 2010. Credit constraints and adoption of modern cassava production technologies in rural farming communities of Anambra State, Nigeria. African Journal of Agricultural Research 5(24): 3379-3386.

Ostwald, M. and D. Chen. 2006. Land-use change: impacts of climate variations and policies among smallscale farmers in the Loess Plateau, China. Land Use Policy 23(4): 361-371.

Petrick, M. 2004. Farm investment, credit rationing, and governmentally promoted credit access in Poland: a cross-sectional analysis. Food Policy 29(3): 275-294.

Porgo, M., J.K.M. Kuwornu, P. Zahonogo, J.B.D. Jatoe and I.S. Egyir. 2018. Credit constraints and cropland allocation decisions in rural Burkina Faso. Land Use Policy 70: 666-674. https://doi.org/10.1016/j. landusepol.2017.10.053

Rao, C., J. Samuel, S. Kumar, B. Raju, R. Dupdal and B. Venkateswarlu. 2014. Role of technology and credit in improving farm incomes in rainfed regions in Andhra Pradesh. Agricultural Economics Research Review 27(2): 187-198.

Reyes, A. and R. Lensink. 2011. The credit constraints of market-oriented farmers in Chile. Journal of Development Studies 47(12): 1851-1868.

Tran, M.C., C.E. Gan and B. Hu. 2016. Credit constraints and their impact on farm household welfare: evidence from Vietnam's North Central Coast region. International Journal of Social Economics 43(8): 782-803.

Uchida, E., S. Rozelle and J. Xu. 2009. Conservation payments, liquidity constraints, and off-farm labor: impact of the Grain-for-Green Program on rural households in China. American Journal of Agricultural Economics 91(1): 70-86.

Wang, X., F. Yamauchi and J. Huang. 2016. Rising wages, mechanization, and the substitution between capital and labor: evidence from small scale farm system in China. Agricultural Economics 47(3): 309-317.

Zhang, Y., X. Li, W. Song and L. Zhai. 2016. Land abandonment under rural restructuring in China explained from a cost-benefit perspective. Journal of Rural Studies 47: 524-532. 
